substances it arouses the student's interest in these aspects before his attention is concentrated on the theoretical framework of organic chemistry. It is a remarkable fact that this text-book is still in use. He also acted as director of the central bureau concerned with the preparation of the International Catalogue of Scientific Literature published by the Royal Society. The first annual issue of this great work under his directorship was published in 1903 and annual issues followed up to the fifteenth, dealing with the year 1915, after which the work was suspended owing to the War of 1914-18. After peace came, there were great difficulties in the way of resuming the work, and in 1922 it was decided not to continue it further.

Morley's earliest scientific publication appears to have been a paper on the Groves gas battery published in 1878. Another paper published in 1878 was one with L. Claisen describing the preparation of phenylglyoxylic acid and its ethyl ester by the interaction of ethyl oxalyl chloride and mercury diphenyl. In 1879. he investigated, with $\mathrm{C}$. Wurster, the methylation of $m$-phenylene diamine and obtained the tetramethyl derivative. $\mathrm{He}$ also examined the astion of nitric acid on the new compound. In the sams year he studied the action of nitrous acid on diphenylethylene diamine and diphenyldiethylene diamine, obtaining the nitrosamines, from the second of which he prepared diphenyl diethylene tetramine.

In 1880 some work on bases allied to choline was published. The interaction of monochlorhydrin with mono- or dimethylamine was found to give methyl diox-ethylene diamine and the corresponding dimethyl compound. The action of propylene and isopropylene chlorhydrins with trimethylamine gave the trimethyl hydroxy propylamine chloride and the corresponding iso compound. By the interaction of chlorhydrin with mono- and dimethylamines he obtained the mono- and dimethyldioxy ethylene amines.

In 1882 the action of an aromatic amine ( $p$-toluidine) and propylene oxide was tried, and oxypropyl $p$-toluidine was isolated as a crystalline solid. In 1885 he worked with A. G. Green on the constitution of the propylene chlorhydrin obtained from glycerin. It was shown to be mainly $\mathrm{CH}_{3} \mathrm{CH} \mathrm{OH} \mathrm{CH}_{2} \mathrm{Cl}$, but an admixture of the isomer was not excluded. The action of zinc ethide on the benzoyl derivative of the chlorhydrin was investigated and found to follow a somewhat unexpected course, giving rise to a member of a new series of compounds which were named 'ketates'. In the course of this work propiophenone was prepared for the first time in solid form. In the same year, in conjunction with W. J. Saint, he prepared and investigated ethyl thioxalate. Two years later he wrote some criticism of H. E. Armstrong's views on substitution in the benzene nucleus. In 1891 he published, in conjunction with E. Hari, an account of the $p$ - and iso-propyl $p$-toluidines.

Morley did not entirely retire until he was eighty. four, when he resigned from his last examinership on his wife's persuasion-although he was asked to continue for a further year.

A man of happy disposition and simple tastes, he loved to welcome his friends to his house at Hampstead or to his quiet home and garden in Midhurst, the peace of which was rudely disturbed by enemy action a few weeks before his death. He himself fortunately escaped injury.

\section{Prof. A. A. Boon}

ThE death occurred in Edinburgh on April 1 of Prof. Alfred Archibald Boon, emeritus professor of chemistry in the Heriot-Watt College. He was seventy-six years of age, unmarried, and had been in failing health for some years.

Born in India, where his father was in the Indian Medical Service, Boon graduated B.A. at the University of Madras, then went to the University of Edinburgh to study chemistry under Crum Brown and natural philosophy under Tait, whose lectures appealed to him very much. He graduated B.Sc. in 1898, then took the D.Sc. degree in 1905, his researches being in the field of organic chemistry. Boon was always keenly interested in the medical and pharmacological aspects of chemistry.

For some years Boon was on the staff of one of the training colleges in Edinburgh and was also a part-time member of the chemistry staff of the Heriot-Watt College. On two occasions, he conducted courses for teachers in Dublin on the invitation of the Board of Agriculture and Technical Instruction for Ireland. He soon became a full-time member of the staff of the Heriot-Watt College as lecturer in organic chemistry and, on the death of Prof. John Gibson, became acting head of the Chemistry Department in 1913. In 1919, he was appointed professor of chemistry, a post which he held until his retirement in 1931 with the title of emeritus professor.

Boon was a very able teacher and took great care in the supervision and administration of his Department, which developed greatly under his direction, among the developments being courses in papermaking, brewing, and pharmacy. The interests of his Department and of his students came first; he never seemed to forget a student. The heavy administrative and teaching work he had to bear gave him little opportunities for research, to which, however, he made contributions. In all his teaching he always stressed the great importance of fundamental principles.

During the War of 1914-18, he undertook investigations for the Services, particularly for the Admiralty, such as the systematic examination of oils collected from the surface of the North Sea whenever a German submarine was destroyed, the first of these being at Fidra in the Firth of Forth.

On several occasions, Boon served on the Council of the Institute of Chemistry, he was for many years a member of the Board of Examiners in Scotland of the Pharmaceutical Society of Great Britain, and served on several committees dealing with the training of pharmacists.

A man of deep religious convictions; Boon was a hater of injustice, was very conscientious, fairminded, and helpful to any who sought his aid or advice. A cricketer and a swimmer in his younger days, he took up golf in later years and enjoyed his holiday in North Berwick; he became an able player, as many of his friends found. To those who knew him he was a true friend.

F. J. WILSON.

WE regret to announce the following deaths :

Sir Thomas Middleton, K.C.I.E., K.B.E., C.B., F.R.S., chairman of the Agricultural Research Council since 1938, on May 14, aged seventy-nine.

Sir Arthur Newsholme, K.C.B., sometime principal medical officer under the Local Government Board, on May 17, aged eighty-six. 